\title{
Looking for evidence of climate change impacts in the eastern Irish Sea
}

\author{
L. S. Esteves ${ }^{1}$, J. J. Williams ${ }^{2}$, and J. M. Brown ${ }^{3}$ \\ ${ }^{1}$ Cities Institute, London Metropolitan University, Ladbroke House, 62-66 Highbury Grove, London, N5 2AD, UK \\ ${ }^{2}$ ABPMer, Suite B, Waterside House, Town Quay, Southampton, SO14 2AQ, UK \\ ${ }^{3}$ National Oceanographic Centre, Joseph Proudman Building, 6, Brownlow Street, Liverpool, L3 5DA, UK
}

Received: 10 February 2011 - Revised: 13 April 2011 - Accepted: 26 April 2011 - Published: 14 June 2011

\begin{abstract}
Although storminess is often cited as a driver of long-term coastal erosion, a lack of suitable datasets has only allowed objective assessment of this claim in a handful of case studies. This reduces our ability to understand and predict how the coastline may respond to an increase in "storminess" as suggested by global and regional climate models. With focus on $16 \mathrm{~km}$ of the Sefton coastline bordering the eastern Irish Sea (UK), this paper analyses available measured datasets of water level, surge level, wave height, wind speed and barometric pressure with the objective of finding trends in metocean climate that are consistent with predictions. The paper then examines rates of change in shoreline position over the period 1894 to 2005 with the aim of establishing relationships with climatic variability using a range of measured and modelled metocean parameters (with time spans varying from two to eight decades). With the exception of the mean monthly wind speed, available metocean data do not indicate any statistically significant changes outside seasonal and decadal cycles. No clear relationship was found between changes in metocean conditions and rates of shoreline change along the Sefton coast. High interannual variability and the lack of long-term measurements make unambiguous correlations between climate change and shoreline evolution problematic. However, comparison between the North Atlantic Oscillation winter index (NAOw) and coastline changes suggest increased erosion at times of decreasing NAOw values and reduced erosion at times of increasing NAOw values. Erosion tends to be more pronounced when decreasing NAOw values lead to a strong negative NAO phase. At present, anthropogenic changes in the local sediment budget and the short-term impact of extreme events are still the largest threat likely to affect coastal flooding and
\end{abstract}

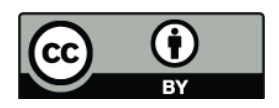

Correspondence to: L. S. Esteves (1.slompesteves@londonmet.ac.uk) erosion risk in the short- and medium-term. Nevertheless, the potential impacts of climate change in the long-term should not be ignored.

\section{Introduction}

Climate change is expected to affect the frequency, trajectory and intensity of storms (IPCC, 2007) which in turn may increase the occurrence of extreme water levels through the combined effect of rising sea level and higher storm surges (e.g. Wang et al., 2008). A number of studies have examined long-term trends of storm surges and sea level (e.g. Woodworth and Blackman, 2002; Woodworth et al., 2007, 2009), and the potential impacts of climate change for the UK (e.g. Lowe et al., 2001; Lowe and Gregory, 2005; Senior et al., 2002; Tsimplis et al., 2005). The main results indicate that, in England, sea level is rising (e.g. Woodworth et al., 2009) and, based on more than $200 \mathrm{yr}$ of tidal records at Liverpool, both annual maximum high water and surge at annual maximum high water have not shown long-term change (Woodworth and Blackman, 2002). However, Woodworth and Blackman (2002) found that values of annual maximum surge at high water were larger at the end of the last three centuries than for most of the 20th century, and suggest: (a) the findings are consistent with known variations in storminess in the region; and (b) there is a secular trend in the distribution shape of storminess, with enhanced storminess at the beginning and end of centuries in comparison to mid-century. Model projections indicate that climate change might result in increased storm surge heights at most locations in the UK by the end of this century and higher sea level will lead to higher extreme water levels (e.g. Lowe and Gregory, 2005). The projected increases in storm surges and extreme water levels are expected to intensify coastal erosion (e.g. Keim et

Published by Copernicus Publications on behalf of the European Geosciences Union. 
al., 2004; Lozano et al., 2004; Tsimplis et al., 2005). Erosion is already critical at some locations along the eastern Irish Sea shoreline, resulting in a reduced level of flood protection provided by natural coastal features. What remains unclear is whether observed changes in storminess and coastal erosion can be unquestionably attributed to impacts of climate change, or whether they can be explained otherwise.

If it is assumed that the impacts of climate change are already affecting storminess, an increase in coastal erosion should be evident. Impacts of climate change on metocean conditions and shoreline change are expected to exhibit a consistent long-term trend that should be measurable once higher frequency variations and shorter natural cycles are removed. Therefore, anthropogenic-induced coastal changes must be evaluated since these occur at magnitudes and temporal scales that can override and mask long-term natural changes. By focusing on a well-studied and data-rich 16-km long section of the Sefton coastline (NW England, Fig. 1), this paper looks carefully for evidence of trends in a range of metocean parameters, and for links between any identified trends and observed changes in the rate of coastal evolution. The longest available measured and modelled datasets from the eastern Irish Sea and wider areas include tide levels, surge heights, wind speeds, and wave heights. These are examined first for evidence of long-term changes in the metocean climate. The paper then presents data defining the rate of change in shoreline position at the study site derived from a range of historical maps and aerial photographs for the period 1894 to 2005 . The primary aim here is to assess whether temporal changes in the rates and magnitudes of coastal erosion can be attributed to the observed trends in metocean data, and if these trends can, in turn, be associated with climate change or other cycles such as the North Atlantic Oscillation (NAO). A better understanding of the linkages between changes in metocean conditions and coastal erosion contributes to evidence-based coastal management, especially to plan for changes in coastal evolution driven by climate change and/or long-term natural cycles.

\section{The study area}

The Sefton coast borders the eastern Irish Sea (UK) and extends for $36 \mathrm{~km}$ between the Mersey and the Ribble estuaries. The study site comprises of a $16-\mathrm{km}$ long undefended dune frontage extending from north of Hightown to Southport (Fig. 1). These dunes have high recreational and conservation value and act as an effective coastal flood defence for urban development (Fig. 1a, d), high-grade agricultural land and conservation areas of national and international importance. Although in many cases in the eastern Irish Sea the position of the coastline is highly influenced by human activities (cf. Stott et al., 2006), the study focuses on a coastal stretch where response to dynamic processes is essentially unconstrained. Consequentially, although the coastal mor- phology is also influenced by changes in the sediment budget caused by human activities, it is able to respond to changes in wave energy, wind and water levels in a "natural" way.

The area experiences a semi-diurnal, macrotidal regime, with mean spring tidal range of $8.22 \mathrm{~m}$ at Liverpool (c. $9 \mathrm{~km}$ south of the study area) and $9.56 \mathrm{~m}$ at Heysham ${ }^{1}$ (c. $45 \mathrm{~km}$ north of the study area, Fig. 1). Storm surge heights are normally $<0.5 \mathrm{~m}$ but can exceed $2 \mathrm{~m}$ during extreme events (e.g. Brown et al., 2010). Locally, the limited fetch restricts wave development, while topographic and bathymetric features limit the incursion of Atlantic swell into the southern parts of the Irish Sea (Gresswell, 1967a; Brown and Wolf, 2009). Based on an 11-yr wave-surge modelling hindcast for Liverpool Bay (WaveNet location $53^{\circ} 32^{\prime} 02 \mathrm{~N}$, $003^{\circ} 21^{\prime} 19 \mathrm{~W}$ ), the mean annual significant wave height is $0.53 \mathrm{~m}$ and the extreme 1 in 50 -yr wave height is estimated to be $7.3 \mathrm{~m}$ (Brown et al., 2010).

Formby Point (defined here as the coast between South Lifeboat Road and Freshfield, Fig. 1) is considered to be a divergent sediment cell boundary, where a rapidly eroding beach/dune system (Fig. 1c) supplies sediments to the accreting shores northward and southward (Gresswell, 1967a, b; Pye and Blott, 2008). Along a 4-km long dune frontage extending northwards from South Lifeboat Road, rates of dune retreat of up to $5 \mathrm{~m} \mathrm{yr}^{-1}$ were measured from 2001 to 2008 (Esteves et al., 2009). Dune retreat along the Sefton coast occurs when high water levels allow waves to reach the dunes, causing soaking of the dune toe and wave undercutting (Pye and Blott, 2008). Therefore, dune erosion occurs only when water levels reach the dune toe, which usually requires storm surges to coincide with high spring tides (cf. Esteves et al., 2011). Analysis of beach profiles and dune toe positions shows a large spatial variability in the trends and magnitudes of changes (cf. Pye and Blott, 2008; Esteves et al., 2009; Esteves and Williams, 2011).

Historical data suggest accretion of up to $4 \mathrm{~m} \mathrm{yr}^{-1}$ along the Sefton coastline from $c .1850$ to 1906, with largest accretion occurring along the northern half of Formby Point (Gresswell, 1967a, b). Dune erosion started in early 1900s (e.g. Gresswell, 1967a, b; Pye and Blott, 2008) and was more intense along the northern section of Formby Point, where previously largest accretion was observed (Gresswell, 1967a). Gresswell (1967a, b) suggested that the erosive trend was determined by a reduction in the offshore sediment supply due to a more northerly approach of the dominant wind and waves. Waves approaching from the prevailing westerly direction interact with the sand banks, transporting sediment onshore, but reach the coast with less energy. Changing the direction by a few degrees northwards causes the waves to propagate over deeper sections of the banks, reducing rates of sediment supply to the shoreline and resulting in enhanced beach erosion. When considering the evolution of the Sefton

\footnotetext{
${ }^{1}$ National Tidal and Sea Level Facility (http://www.pol.ac.uk/ ntslf)
} 


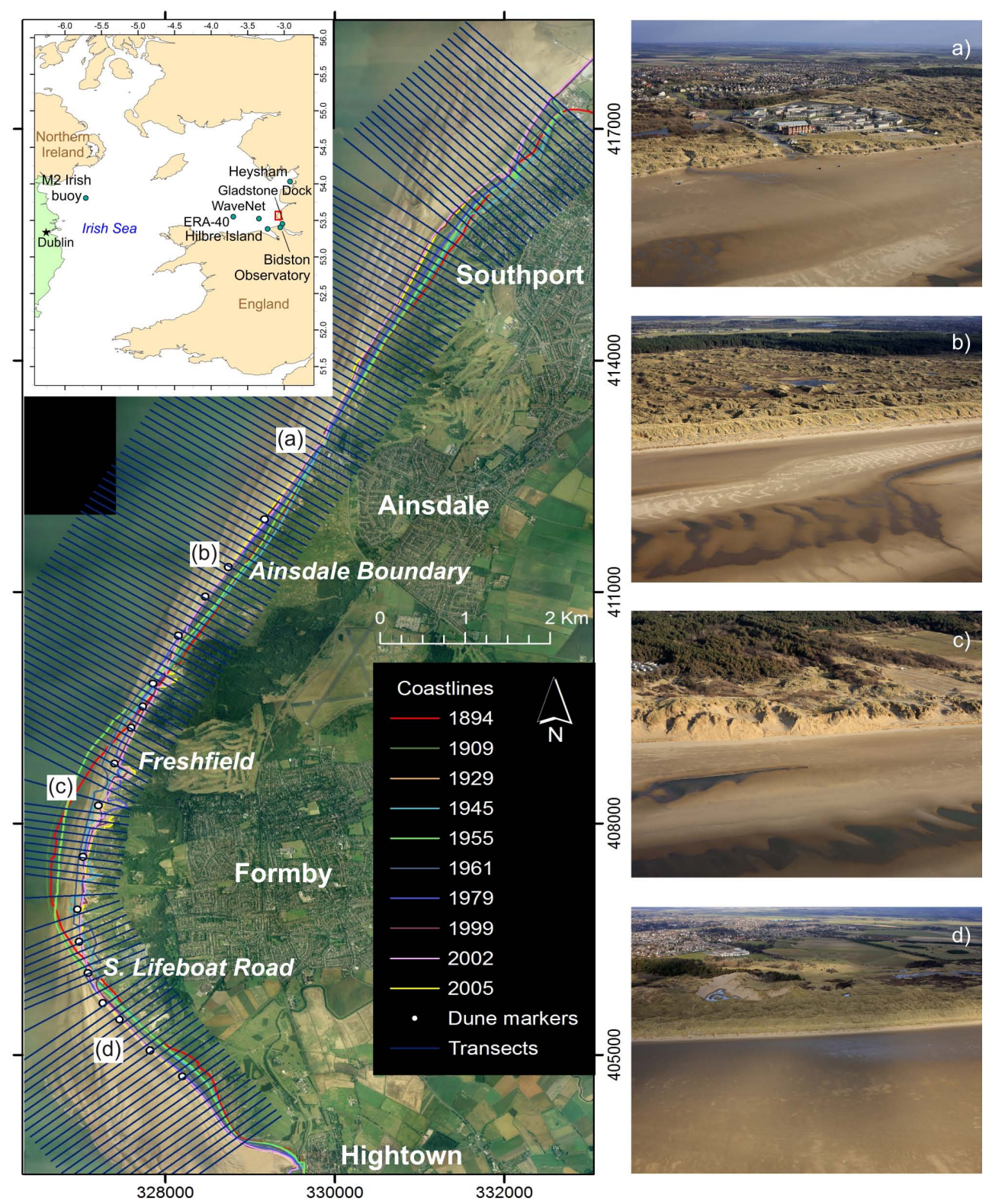

Fig. 1. Field site location showing the position of the coastline at different times and the shoreline transects along which coastline changes were measured. The inset shows the stations where metocean data were collected and the location of the study area (red rectangle). Photographs of the coastline at four locations show: (a) urban development at Ainsdale; (b) accreting dunes south of Ainsdale; (c) eroding dunes at northern Formby Point; and (d) stable vegetated dunes north of Hightown.

coastline, particular attention must be paid to the dredging activity in the river Ribble since 1839 (Barron, 1938) and in the river Mersey since 1890 (McDowell and O'Connor, 1977). As a result, channel depths have varied greatly and sand banks have grown due to dredging disposal (Gresswell, 1967a). The erosion phase of Formby Point is approximately coincident with the time when the dredging at Liverpool increased to over 10 million hopper tons per year in 1906 . The increase in extraction is also coinciding with observations of increased offshore seabed gradient, which has been linked to beach erosion (Gresswell, 1967a). This activity created pits that are thought to have effectively trapped sediment transported shorewards, reducing sediment supply to the beaches (Blott et al., 2006). This view is not supported by a commissioned report for Westminster Dredging (HR Wallingford, 2001) where it is argued that dredging per se would not disrupt the beach sediment supply. Gresswell (1967a) discussed the influence of natural and artificial changes in the configuration of nearshore and offshore sand banks and channel system on the onset of erosion at Formby, but considered 
these important only when taking into account the direction of dominant winds and waves.

Dune erosion at Formby Point continued in the second half of the 20th century and extended further northwards towards Ainsdale (Pye and Blott, 2008; Esteves et al., 2009). From 1958 to 2007, dune accretion dominated north of Ainsdale Boundary and south of Lifeboat Road at rates reaching $4 \mathrm{~m} \mathrm{yr}^{-1}$ (Pye and Blott, 2008). Although there has been a trend of reduced erosion rates at most locations since the late 1970s, there is evidence of increased erosion between Lifeboat Road and Ainsdale Boundary since the 1990s. Pye and Blott (2008) suggest that slower rates of erosion between 1970 and 1990 were due to fewer extreme storms and high tides, while the increase in erosion since 1990 is attributable to increased frequency of extreme high tides and waves. These authors also suggest that, although a general relationship is observed between the erosion trend from 1900s and an increase in the NAO Index, changes in offshore and nearshore bathymetry are likely to be a more important driving factor. However, the authors do not explain whether the changes in bathymetry are related to natural dynamic processes (e.g. the impact of storms) or to human activities (e.g. dredging). Further analyses of shoreline changes along the study area at various periods, and the links with metocean parameters and NAO, are presented later in this paper.

\section{Background: predicted long-term metocean trends}

Analysis of tide level measurements worldwide indicates an average rise in sea level around $1.7 \mathrm{~mm} \mathrm{yr}^{-1}$ in the 20th century, while satellite altimetry data obtained from 1993 show a global sea-level rise of $3.1 \pm 0.7 \mathrm{~mm} \mathrm{yr}^{-1}$ (IPCC, 2007). Based on the analysis of long-term tidal records from 1901 to 2006, Woodworth et al. (2009) estimated a mean eustatic sea-level rise of $1.4 \pm 0.2 \mathrm{~mm} \mathrm{yr}^{-1}$ in the UK, which is lower than the global average rate. These authors show that sea-level trends in the UK are influenced by interannual and decadal variations, potentially driven by the "inverse barometer effect", and by large-scale atmospheric and ocean processes such as the NAO. Analysis of $69 \mathrm{yr}$ of complete tidal records from Liverpool in the period 1901 to 2004 shows an estimated sea-level trend of $1.6 \pm 0.17 \mathrm{~mm} \mathrm{yr}^{-1}$ or $1.8 \pm 0.13 \mathrm{~mm} \mathrm{yr}^{-1}$ depending on the method applied (Woodworth et al., 2009). Considering the highest rate of sea-level change for Liverpool estimated by Woodworth et al. (2009), a rise of $14 \mathrm{~cm}$ in sea level from the 2010 levels would be expected by 2080 . In contrast, sea-level rise due to climate change in the UK for a high emission scenario is projected to be $75 \mathrm{~cm}$ by 2080 (Hulme et al., 2002; Woodworth et al., 2009). This would represent an average rate of sea-level rise of $7.1 \mathrm{~mm} \mathrm{yr}^{-1}$ in the next $70 \mathrm{yr}$, which is more than double the $3.1 \mathrm{~mm} \mathrm{yr}^{-1}$ global rate measured by satellite altimetry since 1993, and about four times the long-term rates estimated by Woodworth et al. (2009) for Liverpool.
Using a fine-resolution regional climate model and the Proudman Oceanographic Laboratory ${ }^{2}$ (POL) storm surge model, Lowe and Gregory (2005) analysed changes in the height of 50-yr return period storm surges around the UK by 2080 using the Special Report on Emission Scenarios (SRES) A2 and B2 (IPCC, 2000) for future climate conditions. These model projections indicate that cyclonic systems moving from the west will continue to dominate during the winter and the number of low pressure systems $(<1000 \mathrm{mb})$ crossing the UK will increase from five to eight per winter for SRES A2. Additionally, the storm tracks will move southwards, resulting in a reduction in wind speeds in the north of the UK and an increase in the south. At present, a 50yr return period for storm surges in the eastern Irish Sea is $1.5 \mathrm{~m}$. When sea-level rises $(33 \mathrm{~cm}$ for SRES A2 and $25 \mathrm{~cm}$ for SRES B2) and rates of land movements are included, extreme surge levels are predicted to increase by between $0.2 \mathrm{~m}$ and $0.4 \mathrm{~m}$ (Lowe and Gregory, 2005). The authors compare results with other similar studies and conclude that there is still a low confidence in any particular model attempting to simulate changes in storminess due to climate change. However, the increase in storm surge heights projected by Lowe and Gregory (2005) is within the range indicated by Wang et al. (2008), corroborating the suggestion of enhanced storm surges in the future.

Increasing storminess in the North Atlantic at the end of the 20th century has been suggested by studies based on barometric pressure and/or wind speeds (e.g. Schinke, 1993; Lambert, 1996; Schmith et al., 1998). Concomitantly, several studies indicate a high temporal variability (interannual and interdecadal) in the occurrence of storms in the North Atlantic (Dolan et al., 1989; Schmith et al., 1998; Lozano et al., 2004), which could explain an intensification of storm activity during certain periods (Schmidt et al., 1998; Lozano et al., 2004; Wang et al., 2008). Lozano et al. (2004) have demonstrated that the winter (months: DJFM) NAO index (hereafter termed NAOw) shows a quasi-decadal variability which agrees well with the changes in number of winter storms in the period 1965 to 1995 . However, such agreement is not found for periods before 1960s (Alexandersson et al., 1998). Further complexity to the analysis of changes in storminess is added by the suggestions that while the number of intense storms is increasing, the total number of storms remains unchanged (Sickmöller et al., 2000).

Using the Regional Ocean Model System and the SRES A1B, Wang et al. (2008) estimated changes in wind speeds and storm surge heights of 1 in 10 and 1 in 50-yr return periods in Irish waters for the period 2031-2060. Their model results indicate that, in comparison with conditions in the eastern Irish Sea from 1960 to 1990, maximum annual wind speeds of 1 in 10 and 1 in 50-yr return periods are likely to increase by up to $8 \%$ and $10 \%$, respectively. Similarly, the maximum storm surge heights of 1 in 10 and 1 in 50-

\footnotetext{
${ }^{2}$ Currently named National Oceanographic Centre (NOC)
} 
yr return periods are likely to increase by $10 \%$ to $20 \%$ and $20 \%$ to $30 \%$, respectively (Wang et al., 2008). However, in the Irish Sea the dominance of wind forcing and/or low barometric pressure on surge height varies spatially. Along the southern Irish Sea coasts, the surge height is determined mainly by the inverted barometer effect, while wind forcing is the dominant control along the northern Irish Sea coasts, where it contributes to $72 \%$ of the surge height (Lowe et al., 2001).

Lozano et al. (2004) argue that, although many studies report an increase in coastal erosion rates at the end of the 20th century (e.g. Carter and Bartlett, 1990; Devoy, 2008; Regnauld et al., 2004; Smith et al., 2000; Swift et al., 2003), this is more likely to reflect complex coastal processes (e.g. Carter et al., 1993; Cowell and Thom, 1997; Hardisty, 1994) rather than provide compelling evidence of increased storminess and climate change. The authors based their argument on the fact that despite some evidence of increased wave heights or energy/surge potential in the North Atlantic since the 1970s (Kushnir et al., 1997; WASA, 1998), a reduction in storm frequency and intensity has been observed in the last decades of the 20th century (GTECCA, 1996; Hickey, 2003; Keim et al., 2004). Indeed other studies (e.g. Cooper and Jackson, 2003) provide evidence to support the view that rates of coastal erosion have not changed in the late 20th century. With this range of contradictory evidence it may be concluded that at present no clear pattern of increased storminess is yet discernable on European Atlantic coasts. It is therefore with caution that this present paper attempts to correlate observed changes in the rate of shoreline change with trends in metocean parameters.

\section{Methods}

\subsection{Metocean data}

Local datasets used in this study include: (a) sea-level data $(\text { tide }+ \text { surge })^{3}$ from tide gauges at Heysham $\left(54^{\circ} 01^{\prime} 54.5^{\prime \prime} \mathrm{N}\right.$, $02^{\circ} 55^{\prime} 12.9^{\prime \prime} \mathrm{W}$ ) from 1982 to 2008 and Liverpool Gladstone Dock $\left(53^{\circ} 26^{\prime} 58.8^{\prime \prime} \mathrm{N}, 03^{\circ} 01^{\prime} 05.3^{\prime \prime} \mathrm{W}\right)$ from 1991 to 2009 ; (b) metocean data (significant wave height, Hs, zero-crossing wave period, $\mathrm{Tz}$, wind and atmospheric pressure) from the Irish M2 buoy $\left(53^{\circ} 28^{\prime} 08^{\prime \prime} \mathrm{N}, 05^{\circ} 25^{\prime} 50^{\prime \prime} \mathrm{W}\right)$ for the period 2001 to 2009; and (c) meteorological data from Bidston Observatory $\left(53^{\circ} 24^{\prime} 16^{\prime \prime} \mathrm{N}, 03^{\circ} 03^{\prime} 56^{\prime \prime} \mathrm{W}\right)$ for the period 1929 to 2002 and from Hilbre Island $\left(53^{\circ} 22^{\prime} 56^{\prime \prime} \mathrm{N}, 3^{\circ} 13^{\prime} 36^{\prime \prime} \mathrm{W}\right)$ for the period 2004 to 2010 . In order to lengthen the timespan and complement the observational datasets available for wave parameters, output from the POLCOMS-WAM model related to waves and surge elevation in the eastern Irish Sea

\footnotetext{
${ }^{3}$ Although longer time series are available for sea-level data, these have been extensively analysed in previous studies (Woodworth and Blackman, 2002; Woodworth et al., 2007, 2009), therefore here focus is given to assess changes in the last few decades.
}

(WaveNet location $53^{\circ} 32^{\prime} 02 \mathrm{~N}, 003^{\circ} 21^{\prime} 19 \mathrm{~W}$ ) is examined for the period 1996 to 2007 (cf. Brown and Wolf, 2009; Brown et al., 2010; Appendix 1). Additional temporal coverage was gained using the ERA-40 dataset ${ }^{4}$ for the eastern Irish Sea $\left(53^{\circ} 33^{\prime} \mathrm{N} 03^{\circ} 35^{\prime} \mathrm{W}\right)$ for the period 1960 to 2007.

In order to identify trends indicative of medium- to longterm change, the datasets were each analysed using standard regression techniques. An estimate of the confidence in the results is provided by the computed $p$-value $(p<0.1$ is considered here a statistically significant result) and the squared Pearson correlation coefficient $\left(R^{2}\right)$, which measures the goodness-of-fit of the linear regression. Here the $p$-value is computed by transforming the correlation to create a $t$ statistic having $n-2$ degrees of freedom, where $n$ is sample size. The confidence bounds are based on an asymptotic normal distribution of $0.5 * \log ((1+\mathrm{R}) /(1-\mathrm{R}))$, with an approximate variance equal to $1 /(n-3)$.

In general, maximum and mean monthly and annual values of significant wave height, peak period, and wind speed and direction were used in the analyses of trends. These analyses aimed also to identify trends of increasing frequency and magnitude of extreme water/surge levels and to establish if any detected trends conformed to those expected changes in storminess and potential links with climate change and NAOw. Here, proxies of storminess include increase in magnitude and/or frequency of extreme events (i.e. when parameters exceed specified thresholds). Extreme water levels are defined as the water levels more likely to result in significant erosion along the Sefton coast with values of $10.2 \mathrm{~m}$ above Chart Datum (CD) for Liverpool and $10.5 \mathrm{~m} \mathrm{CD}$ for Heysham (cf. Esteves et al., 2011). Surge levels $>1 \mathrm{~m}$ are considered as being extreme. Although surges can be indicative of storminess, in the study area surges contribute to coastal erosion only when coinciding with high spring tides. An indication of storminess is given by the number of events in each month or year exceeding the specified thresholds: water levels $>10.2 \mathrm{~m} \mathrm{CD}$ at Liverpool and $>10.5 \mathrm{~m} \mathrm{CD}$ at Heysham, wave heights $>4 \mathrm{~m}$, mean wind speeds $>17 \mathrm{~m} \mathrm{~s}^{-1}$ and atmospheric pressure $<980 \mathrm{mb}$. In some cases, a combination of parameters and thresholds was used to identify the number of "storm" events (e.g. wind speeds $>17 \mathrm{~m} \mathrm{~s}^{-1}$ and atmospheric pressure $<980 \mathrm{mb}$ ). A summary of the parameters used in the analyses and respective results are shown in Table 1.

\subsection{Changes in shoreline position}

Rates of change in coastline position $(\Delta s)$ were estimated using the Digital Shoreline Analysis System (Thieler et al., 2009) for the period 1894 to 2005 from: (a) the mapped shoreline positions (error $\pm 10 \mathrm{~m}$ ) from Ordnance Survey topographic maps; and (b) coastline positions extracted from

\footnotetext{
${ }^{4}$ This comprises a re-analysis of the global atmosphere and surface conditions over 40-yr by the European Centre for MediumRange Weather Forecasts (ECMWF).
} 
aerial photographs (error $\pm 15 \mathrm{~m}$ ) using the dune toe or vegetation line as a proxy. The periods examined here were defined based on the availability of good quality data and include: (a) two "long" periods spanning approximately $50 \mathrm{yr}$ (1894 to 1955 and 1955 to 2005); and (b) eight "short" periods (1894 to $1909 ; 1909$ to $1929 ; 1929$ to $1955 ; 1955$ to $1961 ; 1961$ to $1979 ; 1979$ to $1999 ; 1999$ to 2002 ; and 2002 to 2005). These datasets were combined and used to assess whether temporal variations in $\Delta \mathrm{s}$ might be associated with changes in storminess. Erosion and accretion are indicated by negative and positive values of $\Delta \mathrm{s}$, respectively. The data are summarised in Table 2, which gives the minimum, mean, and maximum changes and standard deviation $(\sigma)$ for the rates of change in coastline position $(\Delta s)$ by period.

\subsection{NAOw}

The NAOw is based on the difference between the normalised sea-level pressure measured at Lisbon (Portugal) and Stykkisholmur/Reykjavik (Iceland) for the winter months (DJFM). A link between NAOw and seasonal, interannual and decadal variations in weather (and storminess) for the North Atlantic coast of Europe has been established (e.g. Hurrell and Deser, 2009). Similarly, changes in the rate and characteristics of coastal evolution during the second half of the 20th century have also been linked to modulation of NAOw (e.g. Lozano et al., 2004; O'Connor et al., 2011). These linkages provide a convenient framework within which to assess how local detected trends (if any) in the datasets conform with broad cyclic changes, such as those indicated by the NAOw. NAOw ${ }^{5}$ monthly and annual running average values from 1864 to 2010 are used in this study. In the positive NAOw phase the meridional pressure gradient is enhanced, resulting in stronger westerlies and a shift of storm tracks further north. Since the majority of storms effecting European Atlantic coasts originate in the mid-latitude westerly wind belt (Lozano et al., 2004), increased storminess would be expected during positive phases of the NAOw.

\section{Results and discussion}

\subsection{Trends in metocean data}

Results from the statistical analyses performed on the various metocean datasets are summarised in Table 1. These include: monthly and annual mean and maximum values of barometric pressure; wind speed and direction; wave height and period; and maximum water levels (i.e. tide plus surge) and surge levels. The frequency of events above specific thresholds are also analysed here as an indication of change in storminess. Results shown in Table 1 indicate that: (a) analysed datasets are poorly represented by linear regression (i.e. low $R^{2}$ values); (b) trends are absent or very weak, with

\footnotetext{
${ }^{5}$ Data source: http://www.cgd.ucar.edu/cas/jhurrell/indices.html
}

few exceptions; and (c) most results are not statistically significant $(p>0.1)$. The only statistically significant results $(p<0.1)$ are:

1. Monthly mean wind speeds from Bidston Observatory (Fig. 2a), which show negative trend (with poor linear correlation, $R^{2}=0.023$ ) indicating a reduction in mean wind speeds of $0.12 \mathrm{~m} \mathrm{~s}^{-1}$ per decade.

2. Monthly mean and maximum wind speeds measured by the Irish M2 buoy (Fig. 2b), which show positive trends $\left(R^{2}<0.17\right)$, both indicating an increase in mean and maximum annual wind speeds of $0.24 \mathrm{~m} \mathrm{~s}^{-1}$ per decade.

3. Number of events per month (Fig. 2c) and per year with mean wind speed $>17 \mathrm{~m} \mathrm{~s}^{-1}$ (measured by the Irish M2 buoy), showing positive trends with the largest correlation coefficient of all analyses $\left(R^{2}=0.281\right.$ and 0.546 , respectively). These trends suggest that there will be an increase in 4.2 events with wind speed $>17 \mathrm{~m} \mathrm{~s}^{-1}$ per month in $10 \mathrm{yr}$, while the number of events per year will increase by 48.9 events. However, the short time span of the dataset and the few data points included in the analysis of number of events per year preclude the use of this result in estimating future changes. ERA-40 data also shows a statistically significant positive trend for the number of events per year with mean wind speed $>17 \mathrm{~m} \mathrm{~s}^{-1}\left(R^{2}=0.323\right.$, Table 1$)$. Based on the ERA40 data, the number of events per year will increase by 1.76 events in $10 \mathrm{yr}$, a rate considerably slower than indicated by the M2 Irish buoy.

4. Monthly mean atmospheric pressure measured by the Irish M2 buoy showing a weak positive trend $\left(R^{2}=\right.$ 0.04 ), which represents an increase of $4.8 \mathrm{mb}$ in $100 \mathrm{yr}$.

As presented above, wind data from Bidston Observatory (1929 to 2002, Fig. 2a) show a statistically significant decrease in mean wind speed. Although a similar trend (not statistically significant) is discernable in the Hilbre Island wind record (2004 to 2010, Table 1), these data apparently indicate opposite trends to the M2 wave buoy and to the ERA-40 data. Note that the time period of M2 buoy measurements overlap only partially with the Bidston and Hilbre datasets. These differences might result from exposure to different wind directions at the locations of measurements (Fig. 1). The M2 buoy measurements are taken at sea level close to the coast of Ireland (western Irish Sea), while Bidston Observatory was located on Bidston Hill, Wirral (eastern Irish Sea), with measurements taken at an altitude of $70 \mathrm{~m}$. ERA-40 data were extracted at sea level and deeper waters, more similar to conditions at the M2 buoy. Hilbre Island is located at the mouth of the Dee Estuary, closer to Bidston Observatory. The negative trend in wind speed data from Bidston Observatory is in agreement with the findings of Lowe and Gregory (2005). These authors suggest that changes in climate are likely to 


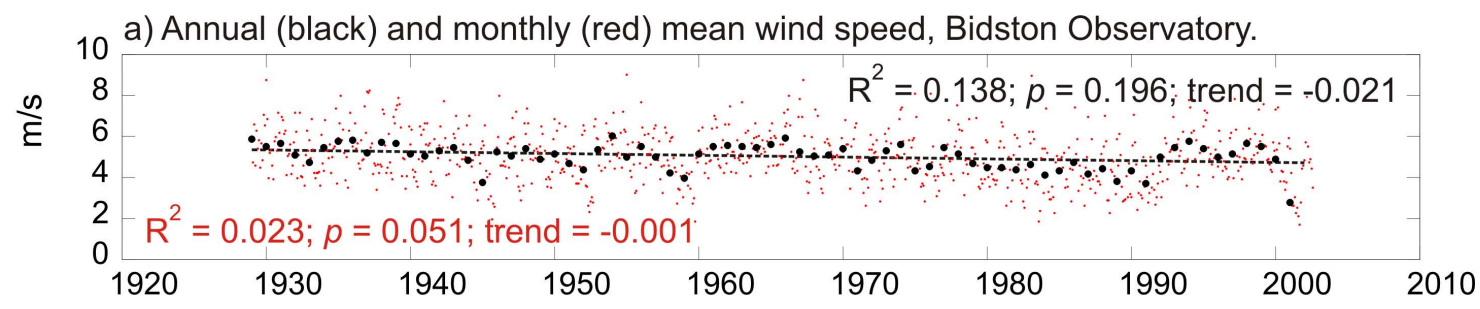

b) Monthly mean wind speed, Irish M2 wave buoy.

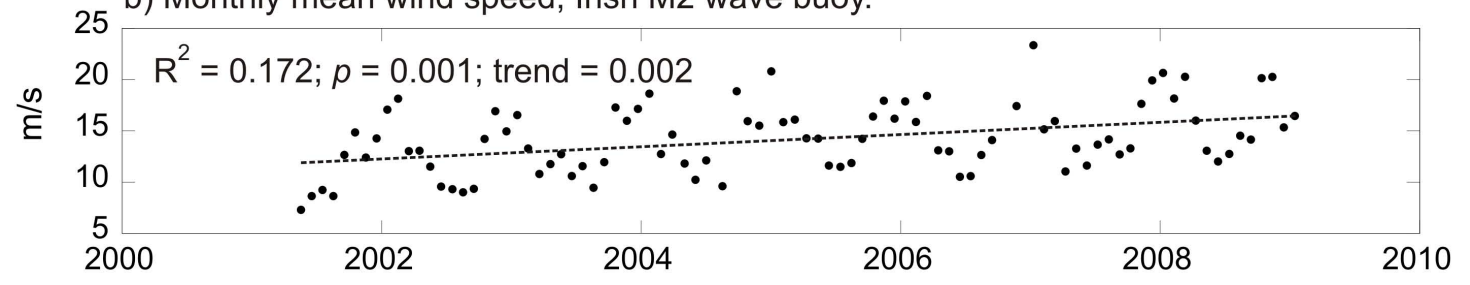

c) Number of wind events per month exceeding $17 \mathrm{~m} / \mathrm{s}$, Irish M2 buoy.

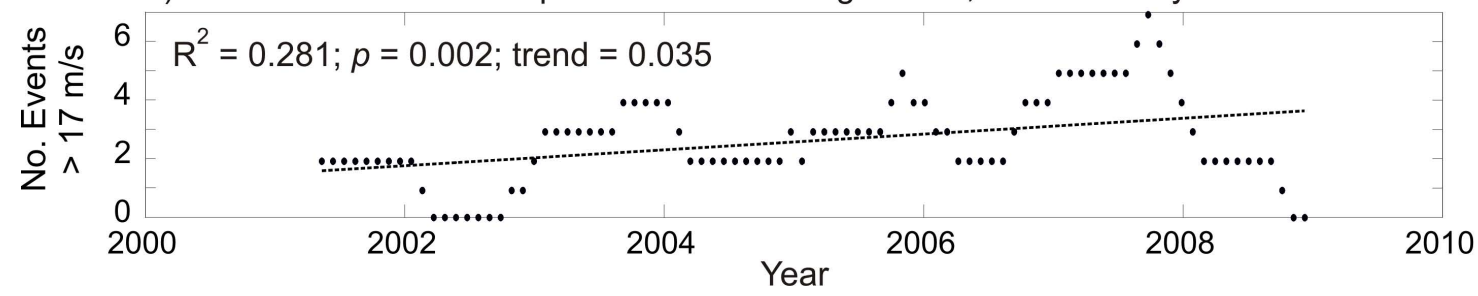

Fig. 2. Examples of the statistically significant results: (a) monthly (red) and annual (black) mean wind speeds from Bidston Observatory (1929 to 2002); (b) monthly mean wind speeds from M2 Irish wave buoy; and (c) number of events per month showing mean wind speeds $>17 \mathrm{~m} \mathrm{~s}^{-1}$ from M2 Irish wave buoy. Dashed lines indicate respective linear trends.

force storm tracks to move southwards, resulting in reduction of wind speeds in the north of the UK and increase in the south.

Changes in wind speed are likely to directly affect surge heights in Liverpool Bay as these are determined mainly by wind forcing along the northern Irish Sea (Lowe et al., 2001). Therefore, a trend of reducing wind speeds (as observed in the Bidston dataset) may result in a decrease in magnitude of surge heights. This is consistent with the findings of Woodworth and Blackman (2002). Their results indicate that no long-term trends in the extreme water levels (surge + tide) in Liverpool were observed in the $232 \mathrm{yr}$ of data (1768 to 2000), while a negative overall trend of $-0.11 \pm 0.04$ m century $^{-1}$ was observed in the values of annual maximum surge at high water. Here shorter time-series of water level data were analysed with the objective of identifying whether, in recent decades, an increase in mean or maximum water levels and surges have occurred. In this study, no trend was observed in the magnitude or frequency of maximum monthly (Fig. 3a) or extreme surge heights $(>1 \mathrm{~m})$ and weak negative trends (not statistically significant) were found for maximum water levels registered at Liverpool Gladstone Docks during the period 1990 to 2009 and at Heysham during the period 1980 to 2009 (Table 1). Therefore, despite the observed rise in mean sea-level (Woodworth et al., 2009), there is no evidence of climate change impact on the magnitude of extreme water levels. This is probably due to a reduction in surge heights caused by the decreasing wind speeds. However, a positive trend (not statistically significant) is observed in the number of events showing extreme water levels at Liverpool (Fig. 3b) and Heysham.

The ERA-40 data indicate that six events showing mean wind speeds $>17 \mathrm{~m} \mathrm{~s}^{-1}$ for more than $3 \mathrm{~h}$ (with 18 events observed in 2007) and six events showing atmospheric pressure $<980 \mathrm{mb}$ (varying from 1 in 1968 to 12 in 2002) occurred per year on average during the period 1960-2007. When both conditions are applied simultaneously (pressure $<980 \mathrm{mb}$ and wind speeds $>17 \mathrm{~m} \mathrm{~s}^{-1}$ ), only an average of two events occurs per year, and a (not significant) weak positive trend can be detected. These results might indicate an increase in storminess at the end of the 20th century, which may be related to a secular shape in the distribution of storminess, identified to be higher at the end of the last three centuries in comparison to mid-century (cf. Woodworth and Blackman, 2002). The identified increase in storminess at the end of the 20th century also coincides with the most recent positive NAOw phase.

There are very few long-term measurements of waves in Liverpool Bay, and thus identifying trends in wave climate is problematic. In the datasets available for this study 
Table 1. Linear regression analysis of metocean datasets for stated periods showing Pearson product moment correlation coefficients $\left(R^{2}\right)$, probability of statistical significance $(p)$ and linear trend.

\begin{tabular}{|c|c|c|c|c|c|}
\hline Dataset & Period & Parameter & $R^{2}$ & $p$ & Trend \\
\hline M2 Buoy: & $03 / 05 / 2001$ to & Monthly max. Hs & 0.000 & 0.984 & 0.000 \\
\hline \multirow{7}{*}{ Station ID: 62091} & \multirow{7}{*}{$31 / 01 / 2009$} & Monthly max. Tz & 0.000 & 0.994 & 0.000 \\
\hline & & Monthly mean wind speed & 0.172 & 0.001 & 0.002 \\
\hline & & Monthly mean wind direction & 0.000 & 0.983 & 0.000 \\
\hline & & Monthly max. wind speed & 0.117 & 0.002 & 0.002 \\
\hline & & Monthly mean atmospheric pressure & 0.040 & 0.061 & 0.004 \\
\hline & & Events per month with mean wind speed $>17 \mathrm{~m} \mathrm{~s}^{-1}$ & 0.281 & 0.002 & 0.035 \\
\hline & & Events per year with mean wind speed $>17 \mathrm{~m} \mathrm{~s}^{-1}$ & 0.546 & 0.056 & 4.890 \\
\hline \multirow{5}{*}{$\begin{array}{l}\text { Bidston Observatory } \\
\text { weather station }\end{array}$} & \multirow{5}{*}{$\begin{array}{l}01 / 01 / 1929 \\
\text { to } 31 / 12 / 2002\end{array}$} & Monthly mean wind speed & $\mathbf{0 . 0 2 3}$ & 0.051 & -0.001 \\
\hline & & Monthly max. wind speed & 0.010 & 0.304 & -0.002 \\
\hline & & Annual mean wind speed & 0.138 & 0.196 & -0.021 \\
\hline & & Annual max. wind speed & 0.102 & 0.394 & -0.055 \\
\hline & & Events per year with mean wind speed $>17 \mathrm{~m} \mathrm{~s}^{-1}$ & 0.029 & 0.808 & -0.012 \\
\hline \multirow{5}{*}{$\begin{array}{l}\text { Hilbre Island } \\
\text { weather station }\end{array}$} & \multirow{5}{*}{$\begin{array}{l}16 / 04 / 2004 \\
\text { to } 01 / 09 / 2010\end{array}$} & Monthly mean wind speed & 0.018 & 0.330 & -9.390 \\
\hline & & Monthly max. wind speed & 0.018 & 0.336 & 0.003 \\
\hline & & Annual mean wind speed & 0.217 & 0.352 & -0.032 \\
\hline & & Annual max. wind speed & 0.014 & 0.822 & -0.003 \\
\hline & & Mean wind speed $>17 \mathrm{~m} \mathrm{~s}^{-1}$ & 0.019 & 0.796 & 0.000 \\
\hline \multirow{5}{*}{$\begin{array}{l}\text { Tide gauge } \\
\text { Liverpool Gladstone Dock }\end{array}$} & \multirow{5}{*}{$\begin{array}{l}01 / 01 / 1991 \\
\text { to } 31 / 12 / 2009\end{array}$} & Annual extreme water level $>10.2 \mathrm{~m}$ & 0.254 & 0.938 & 0.244 \\
\hline & & Annual max. water level & 0.083 & 0.736 & -0.012 \\
\hline & & Monthly max. water level & 0.007 & 0.601 & -0.001 \\
\hline & & Annual frequency surge $>1 \mathrm{~m}$ & 0.038 & 0.878 & -0.000 \\
\hline & & Events per year with water level $>10.2 \mathrm{~m}$ & 0.005 & 0.786 & 0.019 \\
\hline \multirow[t]{5}{*}{ Tide gauge Heysham } & \multirow{5}{*}{$\begin{array}{l}01 / 01 / 1982 \\
\text { to } 31 / 12 / 2008\end{array}$} & Annual extreme water level $>10.5 \mathrm{~m}$ & 0.027 & 0.762 & 0.000 \\
\hline & & Annual max. water level & 0.075 & 0.676 & -0.016 \\
\hline & & Monthly max. water level & 0.029 & 0.834 & -0.001 \\
\hline & & Annual frequency surge $>1 \mathrm{~m}$ & 0.026 & 0.976 & 0.000 \\
\hline & & Events per year with water level $>10.5 \mathrm{~m}$ & 0.008 & 0.844 & 0.020 \\
\hline \multirow{2}{*}{$\begin{array}{l}\text { WAM model } \\
\text { wave predictions }\end{array}$} & \multirow{2}{*}{$\begin{array}{l}01 / 01 / 1996 \\
\text { to } 01 / 01 / 2007\end{array}$} & Annual mean Hs & 0.052 & 0.696 & 0.000 \\
\hline & & Annual max. Hs & 0.045 & 0.641 & 0.000 \\
\hline \multirow{8}{*}{ Re-analysis (ERA-40) } & $01 / 01 / 1960$ & Events per year with pressure $(P)<980 \mathrm{mb}$ & 0.010 & 0.499 & 0.183 \\
\hline & \multirow[t]{7}{*}{ to $31 / 12 / 2007$} & Events per year with mean wind speed $(\mathrm{W})>17 \mathrm{~m} \mathrm{~s}^{-1}$ & 0.323 & 0.000 & 0.176 \\
\hline & & Events per year with combined $\mathrm{P} \& \mathrm{~W}$ & 0.056 & 0.106 & 0.025 \\
\hline & & Events per year with $\mathrm{Hs}>4 \mathrm{~m}$ & 0.010 & 0.587 & -0.006 \\
\hline & & Monthly max. wind speed & 0.000 & 0.751 & -0.002 \\
\hline & & Monthly mean wind speed & 0.000 & 0.679 & -0.002 \\
\hline & & Annual max. wind speed & 0.002 & 0.770 & -0.002 \\
\hline & & Annual mean wind speed & 0.003 & 0.720 & -0.002 \\
\hline
\end{tabular}

(measurements from the M2 Irish buoy and ERA-40 and WAM model results), no trends were found for the analysed wave parameters (Table 1). Analysis of the occurrence of waves characterised by $H s>4 \mathrm{~m}$ based on the ERA-40 dataset shows a slightly decreasing (not statistically significant) trend (Table 1) that conforms with the reduction in wind speeds observed from the Bidston Observatory data (statistically significant) and Hilbre Island (not statistically signif- icant). It is noted that ERA-40 model results underestimate wave heights probably as a consequence of the low resolution of wind data and a relatively poor ability to represent wind directions (Brown et al., 2010). Additionally, Hs is determined by wind speed, wind direction and fetch, and any analysis linking changes in Hs simply in response to a slight change in mean wind speed from any direction would be simplistic at best. Examination of relationships between Hs and winds 


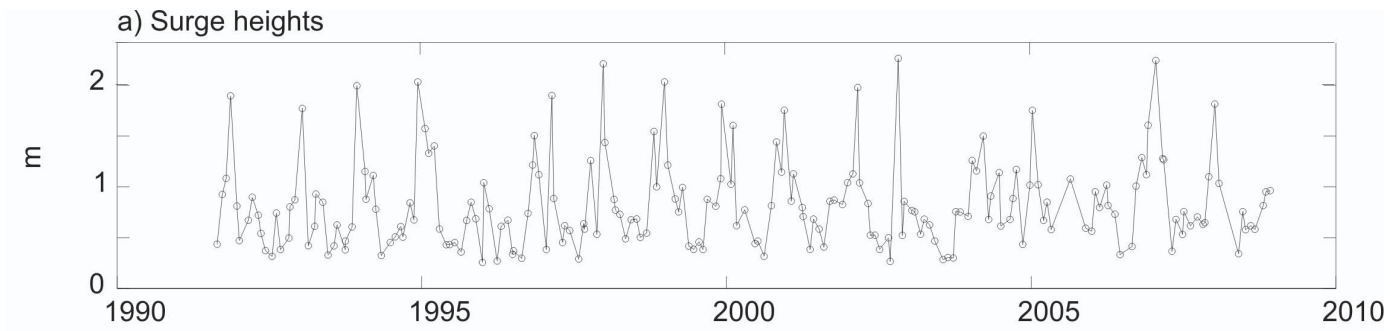

b) Number of events with water levels exceeding $10.2 \mathrm{~m} \mathrm{CD}$

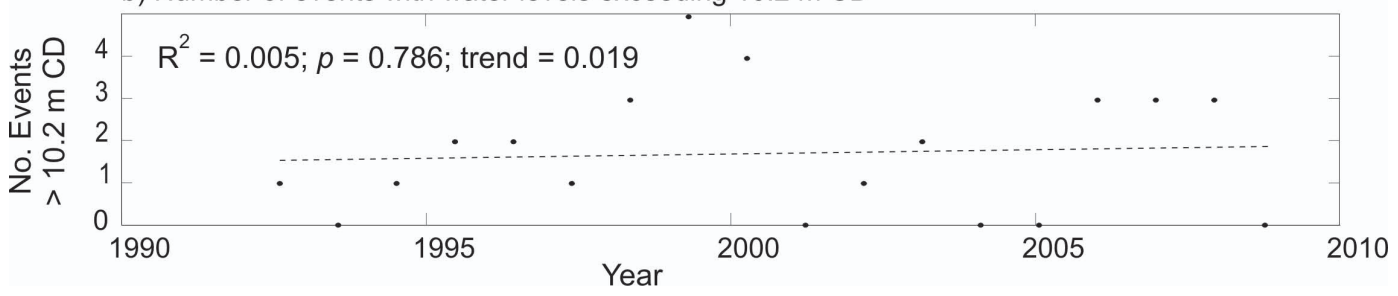

Fig. 3. (a) Maximum monthly positive surge levels and (b) number of events per year of extreme water levels $(>10.2 \mathrm{~m}$ CD) at Liverpool Gladstone Dock from 1991 to 2009. The dashed line indicates the linear trend.

Table 2. Minimum, mean, maximum changes and standard deviation $(\sigma)$ for rate of change in coastline position $\left(\Delta_{S}\right)$ by period.

\begin{tabular}{lrrrr}
\hline \multirow{2}{*}{ Periods } & \multicolumn{4}{c}{$\Delta_{s}, \mathrm{~m} \mathrm{yr}^{-1}$} \\
\cline { 2 - 5 } & $\min$ & $\operatorname{mean}$ & $\max$ & $\sigma$ \\
\hline $1894-1955$ & -1.54 & 0.67 & 3.52 & 0.90 \\
$1955-2005$ & -12.04 & 0.18 & 4.22 & 3.85 \\
\hline $1894-1909$ & -2.50 & 1.19 & 6.48 & 1.52 \\
$1909-1929$ & -7.02 & 0.78 & 6.80 & 2.42 \\
$1929-1955$ & -0.61 & -0.02 & 0.90 & 0.25 \\
$1955-1961$ & -60.03 & -1.98 & 17.68 & 19.27 \\
$1961-1979$ & -20.57 & 0.16 & 9.92 & 4.37 \\
$1979-1999$ & -5.14 & 1.10 & 12.16 & 2.79 \\
$1999-2002$ & -31.38 & -0.33 & 33.41 & 5.93 \\
$2002-2005$ & -55.84 & -0.95 & 14.00 & 8.65 \\
\hline
\end{tabular}

of different mean speeds from different directions failed to find any statistically significant relationships.

The results described above and presented in Table 1 indicate that there is no clear evidence of increasing storminess affecting the Sefton coast that could lead to enhanced coastal erosion. On the contrary, data shows conflicting results, where some (weak) evidence of increased frequency of "storm" events contrasts with trends of reducing mean wind speeds (statistically significant) and maximum water levels (not statistically significant). If we are to believe that these trends are occurring and will continue in the next few decades, it is likely that stormy conditions will be more frequent, but average conditions will show lower mean and maximum wind speeds and maximum water level than at present. However, data clearly show high seasonal and in- terannual variability, resulting in low correlation coefficients and low confidence in the linear trends that might be used to project conditions in the future. Furthermore, since other longer cycles have been identified in some datasets, such as the influence of the NAO in the extreme water levels and surge heights (e.g. Woodworth and Blackman, 2002; Woodworth et al., 2007), simple extrapolation to predict future conditions is subject to considerable error and uncertainty.

\subsection{Coastline position data}

Coastal changes along the Sefton coast from mid-19th century to 2005 are analysed by Esteves et al. (2009), with results indicating that general trends in the changes in coastline and dune toe positions are similar. Here rates of change in coastline position $(\Delta s)$ for two "long-term" $(>50 \mathrm{yr})$ and eight "short-term" (from 3 to $26 \mathrm{yr}$ ) periods are analysed. $\Delta \mathrm{s}$ for all periods are shown in Fig. 4 (note the different scales used on the y-axis). Panels on the right side of the figure show results of a Morlet wavelet transform (Torrence and Compo, 1998) of each $\Delta$ s dataset. The horizontal axis shows the distance along the shoreline from south to north, and the vertical axis represents an alongshore length-scale of observed variations in $\Delta \mathrm{s}$. The minimum and maximum $\Delta \mathrm{s}$ values in a given period are represented by a colour scale, with red colours signifying negative $\Delta s$ values (i.e. erosion), and blue colours signifying positive $\Delta$ s (i.e. accretion). Wavelet analysis is effective in showing the major changes in $\Delta s$ values that occur at a range of different alongshore length-scales and at different locations along the shoreline. A summary of the $\Delta \mathrm{s}$ statistics for each period is shown in Table 2.

Looking at Fig. 4a first, there is a noticeable change in the location and scale of $\Delta \mathrm{s}$ values between the two periods. The 

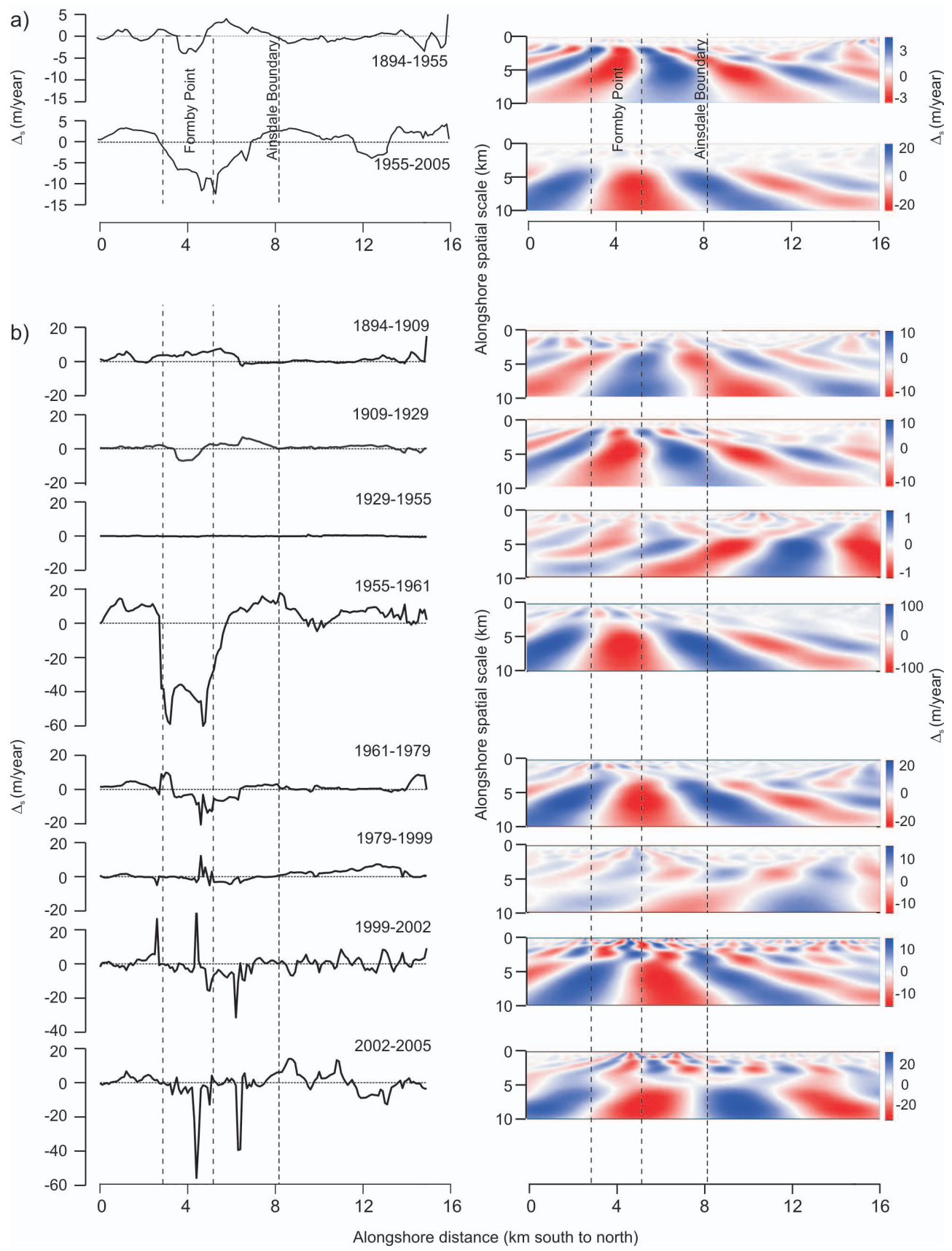

Fig. 4. Time-series (left panels) and wavelet transforms (right panels) showing rate of change in shoreline position ( $\Delta \mathrm{s})$ : (a) for the two longer periods ( $>50 \mathrm{yr}$ ) and (b) for the eight shorter periods (3 to $26 \mathrm{yr}$ ). Dashed lines indicate the position of Formby Point and Ainsdale Boundary (Fig. 1).

period 1894 to 1955 is broadly characterised by relatively small $\Delta s$ values $( \pm 3 \mathrm{~m})$, with a predominance of erosion. Rates of erosion are largest in the centre region of Formby Point, which is flanked either side by zones of accretion. In contrast, $\Delta$ s values for the period 1955 to 2005 are approximately four times larger and, although most of the coastline is accreting, in two marked areas intense erosion is occurring. The major region of shoreline erosion now extends further north of Formby Point into a zone that was rapidly accreting in the preceding period. Concomitantly, areas previously eroding (north of Ainsdale boundary), have shown rapid accretion from 1955 to 2005 . Although $\Delta$ s values have increased and erosion has become more evident in the second period at some locations, this does not apply to the entire coastline. Therefore, a generalised perception of widespread erosion along the Sefton coast cannot be confirmed. 
Looking at $\Delta \mathrm{s}$ in more detail in Fig. $4 \mathrm{~b}$, a number of interesting features are apparent. Firstly, $\Delta s$ values exhibit high temporal and spatial variability with minimum variation ( $\pm 1 \mathrm{~m}, \sigma=0.25 \mathrm{~m}$, Table 2) obtained for the 1929 to 1955 period, and maximum erosion and accretion rates (Table 2) observed in the 1955 to 1961 period. It is interesting also that in most periods before $1979, \Delta$ s were largest in the southern half of the study area. Throughout all periods, Formby Point tends to show the largest $\Delta \mathrm{s}$ values. Although magnitudes of $\Delta \mathrm{s}$ values are variable through time, Formby Point seems to be dominantly eroding, while southward and northward areas are mainly accreting (Fig. 4b). As expected, higher spatial variability in the magnitudes and direction of $\Delta$ s occurs at shorter periods (e.g. 1999 to 2002 and 2002 to 2005). The $\Delta$ s statistics shown in Table 2 represent a quantitative measure of relative dominance of erosion or accretion through time, but the mean $\Delta \mathrm{s}$ is biased towards the largest magnitudes. Therefore, it does not necessarily indicate whether erosion or accretion dominates along most of the coastline, and any assumptions have to be made taking into consideration the alongshore variability as shown in Fig. 4. Such spatial and temporal variability in the patterns of shoreline change present a challenge to establish any relationship with impacts of climate change or other long-term cycles at coastal lengths longer than a few kilometres. Possible links between climate change and the NAO are discussed below.

\subsection{Effects of climate change and NAO}

Results shown here from the analysis of metocean data from the Irish Sea and shoreline changes along the Sefton coast indicate a high temporal and spatial variability at a range of scales. However, there is no evidence of long-term trends that can be linked to climate change in support of the often publicised predictions of future impacts. A rise in mean sea level (i.e. Woodworth et al., 2009) seems to be the only well-evidenced long-term trend observed in the eastern Irish Sea. However, no evidence was found of increasing magnitudes or frequency of extreme high water and surge levels in the last 30 or $40 \mathrm{yr}$. Therefore, if these observed trends (of lack of them) are to continue in the future, it is unlikely that the generalised predictions of a $75 \mathrm{~cm}$ rise in sea level by 2080 or increased maximum water levels due to higher surge heights will be experienced along the Sefton coast. Furthermore, considering that wind forcing contributes to $72 \%$ of the surge height in the northern Irish Sea (cf. Lowe et al., 2001), the identified trends of reducing mean wind speeds at the coast along the eastern Irish Sea are more likely to induce a decrease in surge heights. According to Lowe and Gregory (2005), a reduction in wind speeds in the north of the UK might be caused by a southward move in the storm tracks induced by climate change. The authors also indicate an increase in the number of low pressure systems crossing the UK.
The links between the NAO and temporal variations in storminess and the rates and direction of coastal evolution are analysed here using the NAOw monthly and annual running average values from 1864 to 2010 (Fig. 5). Looking only at the running average value of NAOw, Fig. 5a shows a series of positive and negative phases, each with different amplitudes. The periodicity in the data is better seen in Fig. 5b, which shows a Morlet wavelet transform (Torrence and Compo, 1998) of the NAOw time-series. Although alternating cycles of positive and negative NAOw values occur at a range of time-scales, perhaps of greatest significance are the cycles occurring with a time interval of approximately $80 \mathrm{yr}$. At this scale, the NAOw was strongly positive in the period c. 1900 to 1930, negative between c. 1940 and 1970 and positive again from $c .1980$ to present.

It is evident from Fig. 5 that before 1900, the annual NAOw varied only slightly and was dominantly negative. During the first decades of the 20th century, both storminess and the NAOw have undergone a sustained in-phase change during the instrumental record (e.g. Alexandersson et al., 1998). A positive phase of NAOw started around 1900 and coincided with the occurrence of erosion at Formby Point, while the remainder of the coastline was dominantly accreting (seeing in Fig. 4b, between 1909 and 1929). Previous studies suggest a higher than normal storminess in early 1900s (e.g. Woodworth and Blackman, 2002; Clarke and Rendell, 2009). Between 1909 and 1929, the NAOw remained positive, although values were higher at the beginning and end of the period (Fig. 5). From 1929 to 1955, the coastline was mainly stable, with rates of change $<1 \mathrm{~m} \mathrm{yr}^{-1}$ (Table 2). Apart from the larger positive values at the beginning of the period, NAOw values oscillated between slightly positive and slightly negative. Data from Bidston Observatory indicate a drastic reduction in the mean annual wind speeds in mid-1940, followed by an increase in mid-1950 when the number of events showing wind speeds $>17 \mathrm{~m} \mathrm{~s}^{-1}$ changed from $0-1$ to $2-5$, respectively. Although this might indicate a possible increase in storminess at the end of the period, it did not result in enhanced erosion. From 1955 to 1961 , rapid erosion is evident along $c .4 \mathrm{~km}$ of Formby Point (reaching up to $-60 \mathrm{~m} \mathrm{yr}^{-1}$ ), while accretion dominates elsewhere (up to $17 \mathrm{~m} \mathrm{yr}^{-1}$ ). This period coincides with a reduction in NAOw values and a switch from a positive to a negative phase phase in mid-1950 (Fig. 5). Although there was a marked reduction in mean annual wind speed from 1954 to 1959, it returned to average values in 1960 . This was followed by an increase in the number of events with wind speeds $>17 \mathrm{~m} \mathrm{~s}^{-1}$ (measured at Bidston Observatory). In the period 1961 to 1979 , erosion around Formby Point has reduced considerably and shifted slightly northwards, while accretion rates have also reduced along most of the Sefton coast (Fig. 4b) in comparison with the previous period. Within the second half of this period, the NAOw index gradually increased and changed to a positive phase by 1980 (Fig. 5a). Both the mean wind speeds and the number 

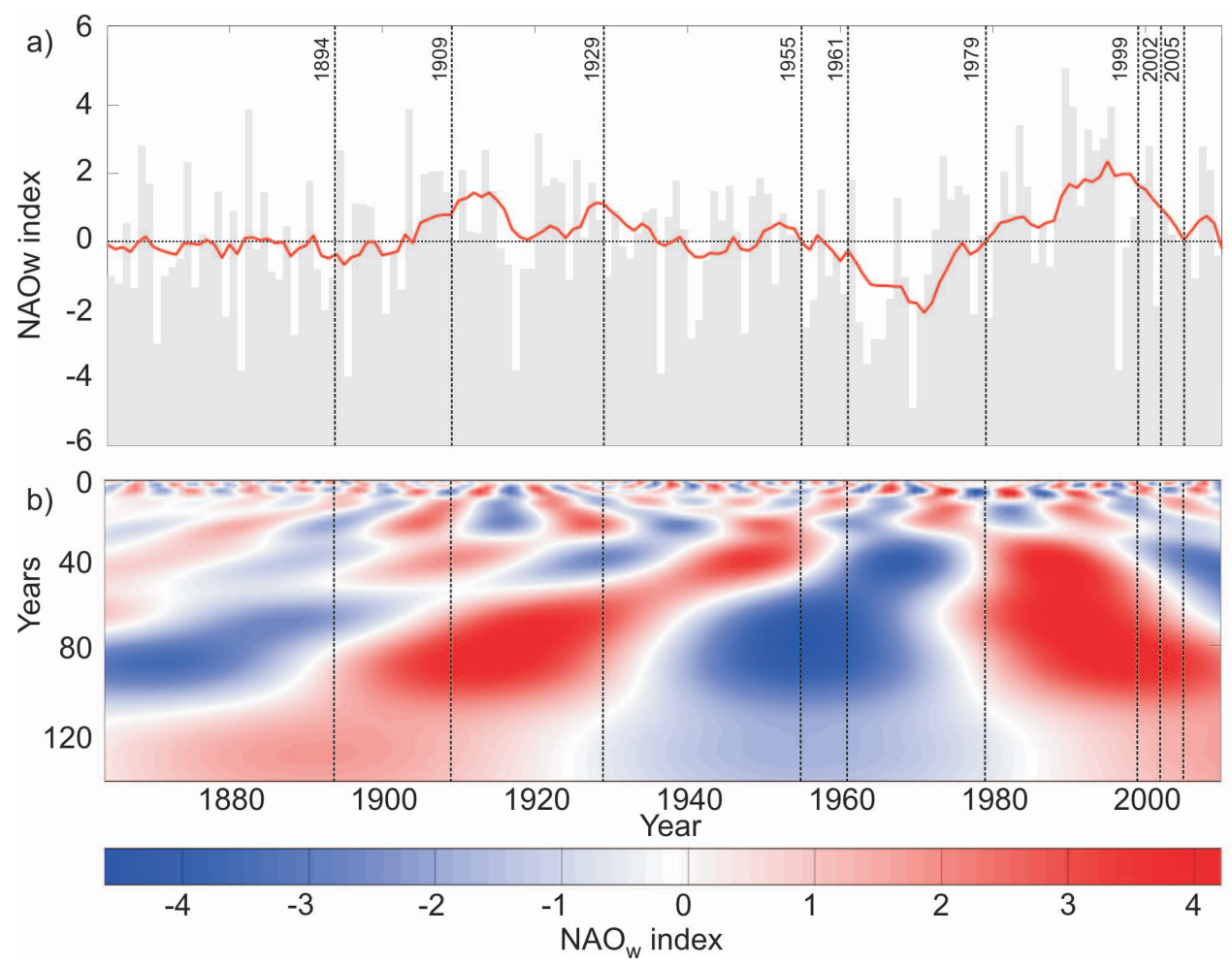

Fig. 5. (a) The monthly NAOw time-series (1864 to 2010) and the annual NAOw running average (red line). (b) Wavelet transform of the NAOw time-series (1864 to 2010). Vertical lines indicate the periods when rates of shoreline change are calculated.

of events with winds $>17 \mathrm{~m} \mathrm{~s}^{-1}$ (from Bidston Observatory) have consistently decreased throughout this period. On the other hand, the ERA-40 data indicate an increase in the number of events with winds $>17 \mathrm{~m} \mathrm{~s}^{-1}$ but a reduction in the number of events showing winds $>17 \mathrm{~m} \mathrm{~s}^{-1}$ and atmospheric pressure $<980 \mathrm{mb}$.

From 1979 to 1999, most of the Formby Point coastline was dominantly stable or accreting (mean $\Delta \mathrm{s}$ is $1.10 \mathrm{~m} \mathrm{yr}^{-1}$, Table 2). In this period, the NAOw index remains positive and increases in value (Fig. 5). Once again, the wind data from Bidston Observatory indicates a reduction in wind activity, while the ERA-40 data show an opposite trend. In the periods 1999-2002 and 2002-2005, there is an alternation of accretion and erosion alongshore and, although erosion still occurs at Formby Point, it is more evident in the latter period (maximum erosion reaching $-55 \mathrm{~m} \mathrm{yr}^{-1}$, Table 2). From 1999 to 2005, the NAOw index is still positive but shows a constant decrease in value (Fig. 5). Although Table 2 and Fig. $4 \mathrm{~b}$ indicate more dominant erosion in the period 2002 to 2005 than from 1999 to 2002, all available datasets indicate more storminess in the latter. The total number of cyclones crossing the North Atlantic has undergone a slight decrease in the last three decades of the 20th century (e.g. Keim et al., 2004). However, the number of intense cyclones has increased (Schinke, 1993; Lambert, 1996; Sickmöller et al., 2000; Keim et al., 2004). A small increase in storminess dur- ing the last two decades of the 20th century was observed in the northeast Atlantic (Woodworth and Blackman, 2002; Schmith et al., 1998; Clarke and Rendell, 2009). However, there is no sign of any absolute change when these results are compared with the storm values found at the beginning of the century (Woodwoth et al., 2009; Clarke and Rendell, 2009). With these results in mind, and the positive and negative NAOw cycles described above, it is noted that an increase in storminess was not clearly observed in the eastern Irish Sea.

The analysis described above indicates that erosion along the Sefton coast is more pronounced in periods of decreasing NAOw values, especially when there is a switch from positive to negative phase (e.g. 1955-1961). Conversely, it seems that rates of erosion are reduced and erosion becomes less extensive during periods of increasing NAOw values, especially when the increase leads to a strong positive phase (e.g. 1894-1909 and 1979-1999). Results here suggest that perhaps the direction and amplitude of change in NAOw values are more important in determining the extension and intensity of erosion along the Sefton coast. However, further analysis comparing datasets of NAOw and shoreline changes over a larger number of shorter-term periods are needed to improve the confidence in these findings. Additionally, the alongshore variability of the coastal changes adds complexity to finding relationships between the NAOw 
or climate change within relatively extended stretches of coastline. Nevertheless, it is interesting that erosion along the Sefton coast tends to occur during negative phases of the NAOw, while most studies suggest that increase in westerly weather and storminess occur during positive NAOw phases. This seems to corroborate with the findings of Gresswell (1967a, b), which suggests that westerly winds and waves interact with local sand banks, supplying sediment to the coast favouring accretion.

Although the modulation of the NAOw appears to have some link with shoreline change, further data characterising a larger range of time/spatial scales is needed to confirm its significance. Linkages between positive NAOw and storminess differ depending on the analysis method, and whether surface or upper-atmospheric characteristics are considered. In general, periods of positive NAOw are characterised by more intense and more frequent storms in the vicinity of Iceland and the Norwegian Sea (Serreze et al., 1997; Deser, 2000). Analysis of the period since the 1960s shows a good agreement between the variations of the NAOw and the interannual variability in the number of storms in the northeast Atlantic (Lozano et al., 2004). The very persistent and positive NAOw of the 1990s is associated with increased wave heights over the northeast Atlantic and decreased wave heights south of $40^{\circ} \mathrm{N}$ (Bacon and Carter, 1993; Kushnir et al., 1997; Wolf and Woolf, 2006). However, this interpretation can be challenged by the evidence of other long-term climatic cycles leading to increased storminess at the end of the centuries (e.g. Woodworth and Blackman, 2002; Woodworth et al., 2007). It is also noted that the sensitivity to NAOw in the UK is small, with the Irish Sea showing a 1$3 \mathrm{~cm}$ change in sea level per unit of NAOw (Tsimplis et al., 2005). Furthermore, wave heights are also insensitive to the NAOw changes, especially in the eastern Irish Sea (Tsimplis et al., 2005). Unfortunately a lack of historical measurements prevents assessment of NAOw effects upon wave direction in the present study area. In areas where data are available, a weak relationship between NAOw and changes in wave direction (maximum change $\pm 20^{\circ}$ ) are demonstrated (e.g. Tsimplis et al., 2005).

\section{Conclusions}

This paper has searched for evidence of linkages between observed changes in metocean and numerical model hindcast data, with climate variability and measured changes in the rate of shoreline change along $16 \mathrm{~km}$ of the Sefton coastline (NW England). Results show no statistically significant trend in most metocean and model datasets and no evidence for an overall increase in coastal erosion through time. The only statistically significant results were related to wind speed data from Bidston Observatory (1929 to 2002) and the M2 Irish buoy (2001 to 2009), which show negative and positive trends, respectively. Differences in the exposure to wind directions between locations of measurements might explain the differences in the observed trends. Our results indicate that data from Bidston Observatory relate better with the observed rates of coastline changes. Usually, reduction in erosion is linked with a trend of reduction in mean wind speeds measured at Bidston. Although a weak (not statistically significant) trend of increasing extreme high water levels over the past two decades at Liverpool is found, there is no evidence that storm surge elevations have increased over the same period.

Erosion of the Sefton coast depends critically on the coincidence of storms and high water levels. Thus, the small measured increase in extreme water levels at Liverpool might enhance coastal erosion, if this increases the probability of storms coinciding with tidal high water. Furthermore, it is unlikely that the coastline will respond to these changes uniformly, and while erosion might increase at some areas (e.g. Formby Point), accretion might dominate elsewhere as occurred at the majority of the studied periods. Attempts to establish other statistically significant correlations between metocean data and $\Delta \mathrm{s}$ values have also proved to be unsuccessful. Although there is evidence of enhanced storminess at some periods analysed here, the impact cannot be detected in the $\Delta \mathrm{s}$ data at time scales of years or decades. This corroborates with the findings of Esteves and Williams (2011) who show that the impact of storms do not significantly contribute to longer-term trends in coastal changes along the Sefton coast.

Periods of strongly positive or negative NAOw appear to have little direct influence on local metocean climate during the time periods examined here. Indeed, periods of negative NAOw, are actually associated with the period of greatest coastal erosion (1955 to 1961). However, it seems that the shifts in the direction in which the magnitude of NAOw values are changing has an influence on the patterns of coastal change. Periods of decreasing NAOw values seem to roughly coincide with periods of enhanced erosion, while periods of increasing NAOw values coincide with periods of less erosion. When the changes in magnitude of NAOw values lead to a shift in NAOw phase, larger coastal changes are observed. It is clear therefore that long-term cyclical variations in wide-area climatic characteristics exert some influence on coastal evolution. However, other factors such as sediment supply and anthropogenic activities might have a more dominant role in determining the temporal and spatial variability of the observed coastal changes.

The results also raise questions about the $\Delta s$ data in this and other studies of climate change impacts on coastlines. It is clear here that the temporal resolution and the period of the observations are critical in accurately determining the coastal evolution at a particular location. However, due to the large spatial variation, it is necessary to quantify rates of change at many locations in order to obtain a comprehensive and accurate view of coastal response to changes in forcing factors. The principal problem with the metocean datasets examined 
here is the relatively short temporal span and the nature of seasonal, decadal, and longer natural climatic variability. Put simply, the present datasets are too short to be able to fully capture the range of natural climatic variance, let alone detect much longer time-scale trends associated with climate change. Additionally, measurements of coastal change are unevenly distributed through time and do not coincide with the shifts in NAOw, making analogies difficult. This problem, combined with the complexity of the coastal sediment system and anthropogenic factors makes the clear, unambiguous establishment of links between short-term trends in metocean parameters and temporal and spatial variations in coastal evolution extremely problematic. At present, it is only possible to identify periods in which rates of coastal change are slowing down or accelerating without being able to identify with certainty the cause(s).

The primary objective of this paper was to establish if contemporary trends in coastal evolution at this site can be used as a guide for coastal managers to anticipate future responses to expected climate change. Data analysed here show no evidence of enhanced storminess or increases in surge heights or extreme water levels. Additionally, the evolution of the coastline analysed at various temporal scales show no strong connection with metocean trends. A link between the NAO and coastal changes has been identified; however, further investigation depends on future regular and continuous coastal monitoring. In a broader context, the longshore variability of coastal response to metocean conditions put in question whether a cause-effect relationship can be established for coastlines longer than just a few kilometres and over the long-term. Consequently, changes in storminess due to climate change are likely to have a variable impact on adjacent coastlines, making regional projections unlikely to be meaningful. Thus, the best immediate recommendation for coastal managers is that anthropogenic changes in the local sediment budget and the short-term impact of storm events coinciding with high spring tides are still the largest threat likely to affect coastal flooding and erosion risk in the short and medium-term. However, the potential impacts of climate change in the long-term should not be ignored. Better understanding of the contribution of long-term climatic changes on the complex natural evolution of this coastline will only be achieved through the acquisition of long-term, high quality datasets of metocean parameters and coastal evolution at the best temporal and spatial resolution possible.

\section{Appendix A}

\section{POLCOMS-WAM modelling in the eastern Irish Sea}

To increase the time-span of datasets on parameters that characterise storm events, a nested model system was used to produce wave-surge results for the eastern Irish Sea for a
11 -year period (01/01/1996 - 01/01/2007). Here, a brief description of the model is provided as further details can be found in Brown et al. (2010). Waves were simulated using the 3rd-generation spectral Wave Model (WAM) set up in a one-way nested approach from a $1^{\circ}$ northeast Atlantic model. The nested models allowed the inclusion of externally generated waves propagating into the Irish Sea and provided hourly boundary forcing to a $1.85 \mathrm{~km}$ Irish Sea model. The coarse grid model was driven by six-hourly, ca. $1^{\circ}$ resolution European Centre for Medium-Range Weather Forecasts (ECMWF) reanalysed ERA-40 wind data. Within the Irish Sea model, a modified version of WAM for shallow water (Monbaliu et al., 2000) was applied. Depth-limited wave-breaking is included only in a further nested Liverpool Bay model where wetting and drying is also included. In the coupled Irish Sea model, WAM uses the same wind forcing provided via the surge model, using hourly Met Office mesoscale model winds. The tide-surge interaction was modelled using the Proudman Oceanographic Laboratory Coastal-Ocean Modelling System (POLCOMS) set up in a one-way nested approach from the $1 / 9^{\circ}$ by $1 / 6^{\circ}$ Operational Continental Shelf surge model (to capture the surge generated outside of the Irish Sea) to a $1.85 \mathrm{~km}$ Irish Sea model. POLCOMS can simulate both the barotropic and baroclinic processes, which arise from the tides, meteorological, and riverine forcing (density effects have not been included here). The turbulence closure scheme (Mellor and Yamada, 1982) has been modified to account for surface wave breaking (Craig and Banner, 1994). For the 11-yr hindcast, hourly wind and pressure data were provided by the UK Met Office northwest European Continental Shelf (mesoscale) model. Wave-tide-surge interaction was taken into consideration through the coupling of POLCOMS-WAM at the Irish Sea model scale. The operational surge model provides total (tide plus surge) hourly elevation and velocity boundary forcing. For the eastern Irish Sea, an improved bathymetric data (NOOS dataset: Zijderveld and Verlaan, 2004) has allowed a $5 \mathrm{~m}$ minimum water depth to be applied $(10 \mathrm{~m}$ minimum depth is used elsewhere). This improved minimum depth allowed resolution of the coastal bathymetric features and prevented numerical instability with drying areas occurring in the model domain due to the tidal variations, thereby improving surge prediction within the eastern Irish Sea (Brown and Wolf, 2009). The coupled POLCOMS-WAM surge predictions in the eastern Irish Sea has been previously calibrated using the November 1977 and January 2007 storm surge events (Brown and Wolf, 2009). Validation of the modelled wave-surge hindcast is provided in Brown et al. (2010). The mesoscale wind forcing for the Irish Sea model was validated using data from the Hilbre met station, situated at the mouth of the Dee Estuary $\left(53^{\circ} 22.94^{\prime} \mathrm{N}, 3^{\circ} 13.60^{\prime} \mathrm{W}\right)$. The mesoscale winds (ca. $12 \mathrm{~km}$ ) are interpolated by POLCOMS onto the Irish Sea model grid (ca. $1.8 \mathrm{~km})$. The model winds are classified by the Cost Function metric to be very good and the direction to be good, while the Percentage Model Bias 
shows the winds are lower than that observed. This may explain why the (locally generated) wave heights are generally under-predicted in the Irish Sea.

Acknowledgements. This study was conducted under the Morphological Impacts and Coastal Risks Induced by Extreme Storm Events (MICORE) project funded by the European Community's Seventh Framework Programme (FP7/2007-2013) under grant agreement $\mathrm{n}^{\circ}$ 202798. The authors would like to thank: staff from Sefton Council for assisting with the datasets; the Met Office for supplying the meteorological data used in the model; and the reviewers J. A. G. Cooper and another reviewer for their contribution to the improvement of this article.

Edited by: J. A. Jimenez

Reviewed by: J. A. G. Cooper and another anonymous referee

\section{References}

Alexandersson, H., Schmith, T., Iden, K., and Tuomenvirta, H.: Long-term variations of the storm climate over NW Europe, Global Atmos. \& Ocean Sys., 6, 97-120, 1998.

Bacon, S. and Carter, D. J. C.: A connection between mean wave height and atmospheric pressure gradient in the North Atlantic, Int. J. Climatol., 13(4), 423-436, 1993.

Barron, J.: A History of the Ribble Navigation, Guardian Press, Fishergate, 1938.

Blott, S., Pye, K., van der Wal, D., and Neal, A.: Long-term morphological change and its causes in the Mersey Estuary, NW England, Geomorph., 81, 185-206, 2006.

Brown, J. M. and Wolf, J.: Coupled wave and surge modelling for the eastern Irish Sea and implications for model wind-stress, Cont. Shelf Res., 29, 10, 1329-1342, 2009.

Brown, J. M., Souza, A. J., and Wolf, J.: An 11-year validation of wave-surge modelling in the Irish Sea, using a nested POLCOMS-WAM modelling system, Ocean Model., 33, 118128,2010

Carter, R. W. G. and Bartlett, D. J.: Coastal erosion in northeast Ireland - Part 1: Sand beaches, dunes and river mouths, Irish Geog., 23, 1-16, 1990.

Carter, R. W. G., McKenna, J., Orford, J. D., and Devoy, R. J. N.: The Irish Sea coast of Ireland: a brief review of coastal processes, erosion and management, in: The Irish Sea Forum Staff (ed.), The Irish Sea, Liverpool, United Kingdom: Liv. Univ. Press, 3 23, 1993.

Clarke, M. L. and Rendell, H. M.: The impact of North Atlantic storminess on western European coasts: A review. Quat. Int., 195, 31-41, 2009.

Cooper, J. A. G. and Jackson, D. W. T.: Geomorphological and dynamic constraints on mesoscale coastal response to storms, Western Ireland, CoastalSed., 3015-3024, 2003.

Cowell, P. J. and Thom, B. G.: Morphodynamics of coastal evolution, in: Coastal evolution, Late Quaternary shoreline morphodynamics, edited by: Carter, R. W. G. and Woodroffe, C. D., Camb. Univ. Press, 33-86, 1997.

Craig, P. D. and Banner, M. L.: Modelling wave-enhanced turbulence in the ocean surface layer, J. Phys. Oceanog., 24, 2546$2559,1994$.
Deser C.: On the teleconnectivity of the Arctic Oscillation, Geophys. Res. Lett., 27, 779-782, 2000.

Devoy, R. J. N.: Questions of coastal protection and the human response to sea-level rise in Ireland and Britain, Irish Geog., 25, (1), 1-22, 1992.

Devoy, R. J. N: Coastal vulnerability and the implications of sealevel rise for Ireland, J. Coastal Res., 24(2), 325-341, 2008.

Dolan, R., Lins, H., and Hayden, B.: Mid-Atlantic coastal storms, J. Coastal Res., 4, 417-433, 1989.

Esteves, L. S. and Williams, J. J.: Characterising the impact of significant dune erosion along the Sefton coast, NW England. Coastal Sed., 684-697, 2011.

Esteves, L. S., Williams, J. J. Nock, A., and Lymbery, G.: Quantifying shoreline changes along the Sefton Coast (UK) and the implications for research-informed coastal management, J. Coastal Res., SI 56, 602-606, 2009.

Esteves, L. S., Brown, J. M., and Williams, J. J.: Quantifying thresholds for significant dune erosion along the Sefton Coast, Northwest England. Geomorph., doi:10.1016/j.geomorph.2011.02.029, 2011

GTECCA: Global Tropical and Extratropical Cyclone Climatic Atlas. Nat. Climatic Data Center, NOAA. U.S. Department of Commerce, 1996

Gresswell, R. K.: Report regarding the Formby coast with special reference to accretion and erosion, and steps which might be taken to ameliorate the present erosion, Formby Urban Dist. Council, 1967a.

Gresswell, R. K.: Report regarding coastal dunes at Formby and particularly regarding a proposal to revise the Formby Coast Protection Order, 1958, Formby Urban Dist. Council, 1967b.

Hardisty, J.: Beach and nearshore sediment transport, edited by: Pye, K., in: Sediment Transport and Depositional Processes, Blackwell Sci. Pubs., Oxford, 219-255, 1994.

Hickey, K. R.: The storminess record from Armagh Observatory, Northern Ireland, 1796- 1999, Weather 58, 28-35, 2003.

HR Wallingford: Dredging in Area 457 in LiverpoolBay, Coastal Impact Study, Stage 1, Rep. EX4389, Wallingford, 2001.

Hulme, M., Jenkins, G. J., Lu, X., Turnpenny, J. R., Mitchell, T. D., Jones, R. G., Lowe, J., Murphy, J. M., Hassell, D., Boorman, P., McDonald, R., and Hill, S.: Climate Change Scenarios for the United Kingdom: The UKCIP02 Scientific Report, Tyndall Centre for Climate Change Res., School of Env. Sci., Univ. East Anglia, Norwich, UK, 120 pp, 2002.

Hurrell, J. W. and Deser, C.: North Atlantic climate variability: The role of the North Atlantic Oscillation, J. Marine Sys., 78(1), 2841, doi:10.1016/j.jmarsys.2008.11.026, 2009.

IPCC: IPCC Special Report on Emission Scenarios. Cambridge, UK, Camb.Univ. Press, 570 pp., 2000.

IPCC: Summary for Policymakers. In: Climate Change 2007: The Physical Science Basis, in: Contribution of Working Group I to the Fourth Assessment Report of the Intergovernmental Panel on Climate Change, edited by: Solomon, S., Qin, D., Manning, M., Chen, Z., Marquis, M., Averyt, K. B., Tignor, M. and Miller, H. L., Camb.Univ. Press, Cambridge, UK and New York, NY, USA, 2007.

Keim, B. D., Muller, R. A., and Stone, G. W.: Spatial and temporal variability of coastal storms in the North Atlantic Basin, Mar. Geol., 210, 7-15, 2004.

Kushnir, Y., Cardone, V. J, Greenwood, J. G., and Cane, M.: On the 
recent increase in North Atlantic wave heights, J. Climate, 10, 2107-2113, 1997.

Lambert, S. J.: Intense extratropical northern hemisphere winter cyclone events: 1899-1991, J. Geophys. Res., 101, 21319-21325, 1996.

Lowe, J. A., Gregory, J. M., and Flather, R. A.: Changes in the occurrence of storm surges around the United Kingdom under a future climate scenario using a dynamic storm surge model driven by the Hadley Centre climate models, Clim. Dynam., 18(3-4), 179-188, 2001.

Lowe, J. A. and Gregory, J. M.: The effects of climate change on storm surges around the United Kingdom, Phil. Trans. Roy. Soc., Ser. A, Math. Phys. Sci., 363, 1313-1328, 2005.

Lozano, I., Devoy, R. J. N., May, W., and Andersen, U.: Storminess and vulnerability along the Atlantic coastlines of Europe: analysis of storm records and of a greenhouse gases induced climate scenario, Mar. Geol., 210, 205-225, 2004.

McDowell, D. M. and O'Connor, B. A.: Hydraulic Behaviour of Estuaries - Chapter 10: Discussion of Case Histories, Macmillan Press, 250-278, 1977.

Mellor G. L. and Yamada, T.: Development of a turbulence closure model for geophysical fluid problems, Rev. Geoph. Space Phys., 20, 851-857, 1982.

Monbaliu, J., Padilla-Hernández, R., Hargreaves, J., Carretero, J. C., Luo, W., Sclavo, M., and Gunther, H.: The spectral wave model, WAM adapted for aplications with high spatial resolution, Coastal Eng., 41, 41-62, 2000.

O’Connor, M., Cooper, J. A. G., and Jackson, D. W. T.: Decadal behaviour of tidal inlet-associated beach systems, northwest Ireland, in relation to climate forcing, J. Sedim. Res., 81, 38-51, 2011.

Pye, K. and Blott, S. J.: Decadal-scale variation in dune erosion and accretion rates: An investigation of the significance of changing storm tide frequency and magnitude on the Sefton coast, UK, Geomorph., 102, 652-666, 2008.

Regnauld, H., Pirazzoli, P. A., Morvan, G., and Ruz, M.: Impact of storms and evolution of the coastline in western France, Mar. Geol., 325-337, 2004.

Schinke, H.: On the occurrence of deep cyclones over Europe and the North Atlantic in the period 1930-1991, Beit. zur Atmos., 66, 223-237, 1993.

Schmith, T., Kaas, E., and Li, T.-S.: Northeast Atlantic storminess 1875-1995 re-analysed, Clim. Dynam., 14, 529-536, 1998.

Senior, C. A., Jones, R. G., Lowe, J. A., Durman, C. F., and Hudson, D.: Predictions of extreme precipitation and sea-level rise under climate change, Phil. Trans. Roy. Soc., Ser. A, Math. Phys. Sci., 360, 1301-1311, 2002.

Serreze, M. C., Carse, F., Barry, R. G., and Rogers, J. C.: Icelandic Low cyclone activity: climatological features, linkages with the NAO, and relationships with, J. Climate, 10, 453-464, 1997.

Sickmöller, M., Blender, R., and Fraedrich, K.: Observed winter cyclone tracks in the northern hemisphere in re-analysed ECMWF data, Quart. J. Roy. Met. Soc., 126, 591-620, 2000.
Smith, D. E., Dawson, A., Dawson, S., Orford, J. D., Devoy, R. J. N., Lozano, I., Hickey, K., Regnauld, H., Andrade, C., Cooper, J. A., Vidal-Roman $\iota$, J. R.: Storminess and environmentally sensitive Atlantic coastal areas of the European Union. Proj. Final Rep. (1997-2000), Comm. Europ. Comm.,EU Contract Nj ENV4-CT97-0488, Brussels, 320 pp., 2000.

Stott, K., Lymbery, G., Wisse, P., and Newton, M.: A review of dredging in the Sefton area, Coastal Defence, Sefton Council, online resource: www.sefton.gov.uk, 20 pp., 2006.

Swift, L. J., Devoy, R. J. N., Gault, J., Wheeler, A. J., and Sutton, G. D.: Contemporary process controls in two mesotidal estuaries. ENVIRON 2003, 13th Irish Environmental Researchers Colloquium, 8-10 January 2003, Environ. Change Inst., NUI Galway, 48-49, 2003.

Thieler, E. R., Himmelstoss, E. A., Zichichi, J. L., and Ergul, A.: Digital Shoreline Analysis System (DSAS) version 4.0: An ArcGIS extension for calculating shoreline change: U.S. Geological Survey Open-File Report 2008-1278, available online at http://pubs.usgs.gov/of/2008/1278/, 2009.

Torrence, C. and Compo, G. P.: A practical guide to wavelet analysis, Bull. Am. Met. Soc., 79, 61-78, 1998.

Tsimplis, M. N., Woolf D. K., Osborn T. J., Wakelin, S., Wolf, J., Flather, R., Shaw, A. G. P., Woodworth, P., Challenor, P., Blackman, D., Pert, F., Yan, Z., and Jevrejeva, S.: Towards a vulnerability assessment of the UK and northern European coasts: the role of regional climate variability, Phil. Trans. Roy. Soc., Ser. A, Math. and Phys. Sci., 363, (1831), 1329-1358, doi:10.1098/rsta.2005.1571, 2005.

Wang, S., McGrath, R., Hanafin, J. A., Lynch, P., Semmler, T., and Nolan, P.: The impact of climate change on storm surges over Irish waters, Ocean Model., 25, 83-94, 2008.

WASA GROUP: Changing waves and storms in the Northeast Atlantic, Bull. Am. Met. Soc., 79, 741-760, 1998.

Wolf, J. and Woolf, D. K.: Waves and climate change in the north-east Atlantic, Geophys. Res. Lett., 33, (L06604), doi:10.1029/2005GL025113, 4 pp.,2006.

Woodworth, P. L. and Blackman, D. L.: Changes in high waters at Liverpool since 1768, Int. J. Climatol., 22, 697-714, 2002.

Woodworth, P. L., Flather, R. A., Williams, J. A., Wakelin, S. L., and Jevrejeva, S.: The dependence of UK extreme sea levels and storm surges on the North Atlantic Oscillation, Cont. Shelf Res., 27, 935-946, 2007.

Woodworth, P. L., Teferle, F. N., Bingley, R. M., Shennan, I., and Williams, S. D. P.: Trends in UK mean sea level revisited, Geophys. J. Int., 176, 19-30, 2009.

Zijderveld, A. and Verlaan, M.: Towards a new gridded bathymetry for storm surge forecastingin the North Sea. EGU 1st General Assembly, Nice, France, 25-30 April 2004, Geophys. Res. Abs., 6, EGU04-A-05177, 2004. 